\title{
Behaviour of Market Arrivals and Prices of the Selected Vegetables: A Study of Baijnath Regulated Market of District Kangra, Himachal Pradesh, India
}

\author{
Jyoti Chaudhary $^{*}$, Harbans Lal ${ }^{1}$ and H.P. Singh ${ }^{2}$
}

${ }^{1}$ Department of Agricultural Economics, IAS, BHU, Varanasi, UP-221005, India

${ }^{2}$ Department of Agricultural Economics, Extension Education and Rural Sociology, CSKHPKV Palampur, HP-176062, India

*Corresponding author

\section{A B S T R A C T}

\section{Keywords}

Arrivals, Prices, Himachal Pradesh, Seasonal fluctuations

Article Info

Accepted:

12 December 2018

Available Online:

10 January 2019
Within horticulture, vegetable production is considered important for agricultural development and the economy of the country as it generates more income and employment and promotes equity when marketing is done rightly. The present study was undertaken to examine the trends, relationship, as well as seasonal fluctuations in arrivals and prices of selected vegetables in Baijnath, regulated market of district Kangra in Himachal Pradesh for the year2010-11 to 2015-16. The analysis shows that the rate of increase in the monthly arrivals is highest for cauliflower whereas for monthly prices it is highest for ladyfinger. The prices of vegetables move contrary to arrivals i.e. prices increased with decreasing arrivals in the market hence negatively correlated. The average monthly variability in arrivals and prices was found the maximum for cucumber and ladyfinger, respectively. The study of seasonal fluctuations in arrivals and prices showed that arrivals of most of the vegetables were higher in the peak season and lower in the lean season. The correlation coefficient calculated from different market prices of vegetables showed that study market was highly integrated with Kangra market for most of the vegetables.

\section{Introduction}

Marketing of horticultural crop is complex especially because of perishability, seasonality and bulkiness. Within horticulture, vegetablesgrowing is considered more important as it generates more income and employment, promotes equity, improves nutrition and protects and conserve environment (Kumar et al., 2005). As far as production is concerned India has emerged as the second largest producer of vegetables with the production of
178 million tonnes (2016-17) next to China and contributes around 14 per cent in the world share. The huge geographical area and several agro-climatic niches in the country exert a strong influence on the supply of most of the agricultural commodities. This increase in agricultural output must be coordinated with changes in the demand and supply for agricultural commodities and marketing, so that producer's share in consumer's rupee increases considerably irrespective of the volume of the marketable surplus with the 
farmers(Sharma and Burark, 2015). Stable prices play an important role in determining the farmer's income. Due to perishability and seasonality of vegetables the producers cannot retain the vegetables at home for a long time thus, have no control over price which leads to price uncertainty. Therefore, the analysis of price behaviour would be useful to take decisions like "when to grow and when to sell" on the part of the farmers and "when, where, how to store and dispose of the produce" on the part of the businessman. The variations between the prices of vegetables received by farmers at the time of harvest and during lean season introduce an element of uncertainty and affect both producers and consumers in case of low prices received and high prices paid.

Therefore, marketing rightly considered an essential activity in addition to improved input like seed and fertilizer in modern agriculture. The study of the relationship between market arrivals and prices is very useful. Larger production and larger arrivals affect adversely to the prices. As a result, the prices usually go down. To achieve the goal of efficient marketing, in-depth studies on seasonal variations and prices are needed. Such studies make the farmers aware of the optimum time to sell their products and also help the policy makers to regulate the supplies and to stabilise the prices. The study has been carried out with the objective to study trends in arrivals and prices, the relationship between arrivals and prices and seasonal fluctuations in the arrivals and prices of selected vegetable commodities.

\section{Materials and Methods}

The data on market arrivals and wholesale prices for different vegetable crops were collected from the APMC Kangra and Baijnath market as well as websites of agricultural marketing (www.agmarknet. nic.in). The data pertains to years 2010-11 to 2015-16. The pattern of market arrivals and prices behaviour of the selected vegetable crops were analysed in term of mean value for each month and the coefficient of variation. Compound growth rates were worked out to examine the trends in market arrivals and prices. The effect of prices on arrivals was worked out using a simple linear regression model. The seasonal indices of monthly arrivals and wholesale prices of vegetables were computed by the using the following formula (Fielder and Osagie 1985)

$\mathrm{SI}_{\mathrm{ij}}=\frac{\mathrm{Y}_{\mathrm{ij}}}{\overline{\mathrm{Y}}_{\mathrm{i}}-(6-\mathrm{j}) \mathrm{b}} \times 100$

where,

$\mathrm{SI}_{\mathrm{ij}}=$ Monthly index for arrivals/prices in $\mathrm{j}^{\text {th }}$ month in $i^{\text {th }}$ year

$\mathrm{Y}_{\mathrm{ij}}=$ Average monthly arrivals (q) /prices (Rs. /q)/ in $\mathrm{j}^{\text {th }}$ month in $\mathrm{i}^{\text {th }}$ year

$\bar{Y}_{\mathrm{i}}=$ Average monthly arrivals $(\mathrm{q}) /$ prices (Rs. /q)/ in $\mathrm{i}^{\text {th }}$ year

$\mathrm{j}=$ Number assigned to month $(\mathrm{j}=1,2$, $3 . . .12$, where $j=1$ for April and $j=12$ for March)

$\mathrm{b}=$ Trend coefficient

\section{Results and Discussion}

\section{Trends in arrivals and prices}

The trend analysis shows the magnitude and direction of change over a period of time. The monthly arrivals of lady finger, cauliflower, pea, radish and potato increased significantly over the time period under consideration (Table 1).

The rate of increase in the monthly arrivals was slightly higher for cauliflower and radish as compared to pea, potato and ladyfinger. The pattern over a period of six years showed an average rising tendency of $3.10 \mathrm{q}, 1.79 \mathrm{q}$, $1.43 \mathrm{q}, 1.22 \mathrm{q}$ and $0.62 \mathrm{q}$ per month in case of cauliflower, radish, pea, potato and ladyfinger. Further, the monthly prices of all the 
vegetables increased significantly over the time period under consideration. The rate of increase in the monthly prices was slightly higher for lady finger, tomato and cauliflower as compared to other vegetables. The pattern over a period of six years showed an average rising tendency of Rs. 24.01/q, Rs. 13.77/q, Rs. 12.05/q, Rs. 11.67/q, Rs. 11.28/q, Rs. 9.48/q, Rs. 9.14/q, Rs. 7.59/q and Rs. 5.29/q per month for ladyfinger, tomato, cauliflower, brinjal, potato, cabbage, cucumber, pea and radish.

\section{Variability in arrivals and prices of major vegetable commodities}

The analysis of variability in monthly arrivals and prices indicates the extent to which marketing system is managing the arrivals in the market Table 2 and 3 .

The Table 2 shows that average monthly arrivals of the cucumber recorded the maximum variability of 77.46 per cent followed by pea (66.09 \%), brinjal $(53.77 \%)$, cauliflower and brinjal (46.27\% to $48.83 \%$ ) the variability in the arrivals of cabbage was to the extent of 37 per cent. The minimum variability of about 16 per cent was recorded in the average monthly arrivals of tomato. This shows that the pattern of monthly arrivals of tomato was more or less uniform around the year.The monthly arrivals were observed to be more than average for the period extending from November to June. In the case of brinjal, the arrivals were more than average during the month of April-May and again in the months of September to November. For lady finger, the arrivals were above average in the postharvest period extending from May to October. The similar type of pattern was also observed in the case of cucumber also. In the case of cauliflower and cabbage, the monthly arrivals were also above average during the months of November to March. The arrivals of pea, radish and potato also exhibited the similar pattern as that of cabbage and cauliflower.

The pattern of average monthly prices of vegetables given in Table 4 reveals that highest variability in the average monthly prices was recorded in case of lady finger $(47.53 \%)$ followed by cabbage $(41.35 \%)$, cucumber $(37.92 \%)$, cauliflower $(35.92 \%)$ and pea $(33.74 \%)$. The variability in the average monthly prices of the other vegetables was recorded to extent of 20 to 26 per cent with the minimum of 20.74 per cent in case of tomato. The average price received for different vegetables were highest in the month of November for tomato, March for brinjal and lady finger, February for cucumber, September for cauliflower and pea, October for cabbage and radish and in the month of November for potato which was the lean seasons of the vegetable arrivals in the market.

\section{Relationship between market arrivals and prices}

The arrivals of vegetables in the market affect their prices to a large extent. The degree of relationship between market arrivals and prices of vegetables was studied by computing correlation coefficients as well as regression coefficients (Table 4). The arrivals and prices of all vegetables were inversely related to each other. Similar results of an inverse relationship between arrivals and prices were reported by (Reddy et al., 2012). The regression coefficients turned out to be negative for all the vegetables but statistically significant only for lady finger, cucumber, cauliflower and pea. This indicated that the arrivals of tomato, brinjal, cabbage, radish and potato had no much effect on their prices.

\section{Seasonal behaviour of prices and arrivals}

The seasonal changes in prices of agricultural produce are caused by the seasonal nature of 
production as farmers cannot store their produce to prevent such changes. These variations affect the income of the farmers adversely because of the inverse relationship between arrivals and prices. The indices of arrivals of tomato were higher during the months of December to June and at a maximum level during May (119.11\%) (Fig. 1) and the price indices were in the month of November $(129.28 \%)$. The seasonal indices of monthly arrivals of brinjal (Fig. 2) were high during the month of April and May, slackened from June to August and again were high during September to November. The price indices were highest in the months of January to March. The seasonal indices of monthly arrivals for ladyfinger (Fig. 3) and cucumber (Fig. 4) were high from April to
October and low from November to March months. The highest arrivals of cucumber $(230.91 \%)$ were noticed in the month of May and lady finger $(184.49 \%)$ in the month of June. The index of arrivals was highest in the month of February for cauliflower (155.25\%) (Fig. 5) and December both for cabbage $(152.94 \%)$ (Fig. 6) and pea (200.34 \%) (Fig. 7) which was the main growing seasons of the vegetables. In case of radish and potato (Fig. 8 and 9), the highest indices of arrivals were found in the month of November (151.42\%) for radish and March (139.62 \%) for potato. The price indices revealed that in case of cauliflower, the price indices were highest in the month of September (170.75\%) For radish and potato price indices were maximum in the month of July and November.

Table.1 Trends in monthly arrivals and prices of vegetables

\begin{tabular}{|c|c|c|c|c|c|}
\hline \multirow{2}{*}{$\begin{array}{l}\text { Sr. } \\
\text { No. }\end{array}$} & \multirow[b]{2}{*}{ Vegetable } & \multicolumn{2}{|c|}{ Arrivals (q) } & \multicolumn{2}{|c|}{ Prices $($ Rs./q) } \\
\hline & & $\begin{array}{l}\text { Constant } \\
\text { (a) }\end{array}$ & $\begin{array}{c}\text { Regression } \\
\text { Coefficient (b) }\end{array}$ & $\begin{array}{l}\text { Constant } \\
\text { (a) }\end{array}$ & $\begin{array}{c}\text { Regression } \\
\text { Coefficient (b) }\end{array}$ \\
\hline 1 & Tomato & 310.31 & $\begin{array}{c}-0.16 \\
(0.77)\end{array}$ & 1086.31 & $\begin{array}{c}13.77^{*} \\
(3.62)\end{array}$ \\
\hline 2 & Brinjal & 78.46 & $\begin{array}{c}0.57 \\
(0.47)\end{array}$ & 813.42 & $\begin{array}{l}11.67 * \\
(2.41)\end{array}$ \\
\hline 3 & Ladyfinger & 45.40 & $\begin{array}{l}0.62^{* * *} \\
(0.34)\end{array}$ & 1915.90 & $\begin{array}{l}24.01 * \\
(8.07)\end{array}$ \\
\hline 4 & Cucumber & 75.58 & $\begin{array}{c}0.53 \\
(0.61)\end{array}$ & 1123.80 & $\begin{array}{l}9.14^{*} \\
(3.56)\end{array}$ \\
\hline 5 & Cauliflower & 127.95 & $\begin{array}{l}3.10^{*} \\
(0.85)\end{array}$ & 1047.68 & $\begin{array}{l}12.05^{*} \\
(3.97)\end{array}$ \\
\hline 6 & Cabbage & 91.55 & $\begin{array}{c}0.37 \\
(0.30)\end{array}$ & 588.02 & $\begin{array}{l}9.48^{*} \\
(2.82)\end{array}$ \\
\hline 7 & Pea & 63.30 & $\begin{array}{l}1.43^{*} \\
(0.52)\end{array}$ & 1272.34 & $\begin{array}{l}7.59 * * \\
(3.23)\end{array}$ \\
\hline 8 & Radish & 65.94 & $\begin{array}{l}1.79^{*} \\
(0.40)\end{array}$ & 522.96 & $\begin{array}{l}5.29^{*} \\
(1.37)\end{array}$ \\
\hline 9 & Potato & 166.19 & $\begin{array}{l}1.22 * * \\
(0.59)\end{array}$ & 526.39 & $\begin{array}{l}11.28^{*} \\
(2.31)\end{array}$ \\
\hline
\end{tabular}

Note: Figures in parentheses indicate the standard errors of the regression coefficients.

*Significant at $1 \%$ level of probability,

**Significant at $5 \%$ level of probability 
Table.2 Average monthly arrivals of vegetables in the market

\begin{tabular}{|l|c|c|c|c|c|c|c|c|c|}
\hline Month & Tomato & Brinjal & $\begin{array}{c}\text { Ladyfi } \\
\text { nger }\end{array}$ & Cucumber & Cauliflower & Cabbage & Pea & Radish & Potato \\
\hline April & 318.67 & 158.67 & 54.67 & 182.00 & 193.67 & 137.83 & 55.50 & 102.33 & 182.00 \\
\hline May & 358.67 & 218.00 & 111.67 & 258.83 & 125.17 & 75.17 & 114.33 & 99.33 & 195.00 \\
\hline June & 323.00 & 96.33 & 118.50 & 154.50 & 111.33 & 67.17 & 71.33 & 66.50 & 158.67 \\
\hline July & 261.67 & 76.83 & 88.17 & 94.17 & 111.58 & 50.00 & 60.33 & 51.50 & 136.17 \\
\hline August & 196.33 & 70.17 & 109.17 & 109.83 & 138.33 & 78.50 & 61.50 & 66.67 & 119.50 \\
\hline September & 242.17 & 121.00 & 99.50 & 108.67 & 153.83 & 75.17 & 44.50 & 103.50 & 167.17 \\
\hline October & 291.83 & 113.83 & 81.00 & 66.33 & 228.83 & 68.50 & 23.00 & 153.67 & 224.17 \\
\hline November & 308.33 & 102.50 & 28.83 & 30.83 & 389.67 & 108.67 & 80.33 & 200.00 & 267.00 \\
\hline December & 334.17 & 76.83 & 11.50 & 21.00 & 380.67 & 164.67 & 234.83 & 196.17 & 282.67 \\
\hline January & 306.00 & 78.83 & 38.67 & 25.83 & 315.67 & 146.00 & 204.00 & 155.00 & 230.67 \\
\hline February & 359.33 & 30.67 & 19.33 & 30.00 & 379.33 & 140.33 & 232.33 & 177.33 & 253.17 \\
\hline March & 354.83 & 46.17 & 54.67 & 55.67 & 365.67 & 147.50 & 204.33 & 205.17 & 311.33 \\
\hline Mean & 304.58 & 99.15 & 67.97 & 94.81 & 241.15 & 104.96 & 115.53 & 131.43 & 210.63 \\
\hline S.D. & 47.87 & 48.41 & 36.55 & 73.44 & 111.57 & 38.36 & 76.35 & 53.96 & 58.03 \\
\hline CV(\%) & 15.72 & 48.83 & 53.77 & 77.46 & 46.27 & 36.55 & 66.09 & 41.06 & 27.55 \\
\hline
\end{tabular}

Table.3 Average monthly prices of vegetables in the market

\begin{tabular}{|l|c|c|c|c|c|c|c|c|c|}
\hline Month & Tomato & Brinjal & Ladyfinger & Cucumber & Cauliflower & Cabbage & Pea & Radish & Potato \\
\hline April & 1635.67 & 1169.00 & 3884.33 & 815.83 & 1006.00 & 544.33 & 1175.00 & 598.17 & 677.67 \\
\hline May & 1173.83 & 1003.50 & 2105.33 & 651.83 & 1436.17 & 572.50 & 1241.67 & 723.83 & 838.00 \\
\hline June & 969.00 & 988.33 & 1199.00 & 860.17 & 1640.33 & 748.17 & 1446.67 & 787.67 & 906.17 \\
\hline July & 1703.50 & 1227.00 & 1402.83 & 1109.50 & 1888.83 & 1016.17 & 2091.67 & 933.00 & 1091.67 \\
\hline August & 1818.33 & 1381.50 & 1522.33 & 1188.67 & 1936.00 & 1325.00 & 2191.67 & 918.00 & 1131.50 \\
\hline September & 1782.17 & 1179.00 & 1579.67 & 1003.33 & 2475.33 & 1152.33 & 2325.00 & 901.33 & 1169.33 \\
\hline October & 1943.17 & 1052.67 & 2038.50 & 1719.00 & 2238.83 & 1645.83 & 2283.33 & 1049.67 & 1172.33 \\
\hline November & 2203.00 & 950.50 & 2261.83 & 1959.17 & 1251.50 & 1554.50 & 1678.33 & 498.00 & 1246.83 \\
\hline December & 1595.17 & 994.17 & 3525.33 & 1861.83 & 1347.17 & 884.83 & 1350.00 & 567.00 & 844.83 \\
\hline January & 1474.33 & 1454.67 & 4565.50 & 2134.50 & 946.83 & 673.50 & 950.00 & 558.50 & 724.83 \\
\hline February & 1240.50 & 1583.33 & 4599.17 & 2314.67 & 661.17 & 525.33 & 908.33 & 491.67 & 695.83 \\
\hline March & 1526.67 & 1887.67 & 4822.50 & 1870.50 & 1023.00 & 565.17 & 950.00 & 564.17 & 757.67 \\
\hline Mean & 1588.78 & 1239.28 & 2792.19 & 1457.42 & 1487.60 & 933.97 & 1549.31 & 715.92 & 938.06 \\
\hline S.D. & 329.51 & 275.53 & 1327.11 & 552.60 & 534.37 & 386.16 & 522.66 & 187.21 & 201.85 \\
\hline CV(\%) & 20.74 & 22.23 & 47.53 & 37.92 & 35.92 & 41.35 & 33.74 & 26.15 & 21.52 \\
\hline
\end{tabular}


Table.4 Effect of arrivals on the prices of vegetables in the market

\begin{tabular}{|c|c|c|c|c|c|}
\hline Sr. No & Vegetable & Constant & Regression coefficient & $\mathbf{R}^{2}$ & $\mathbf{r}$ \\
\hline \multirow[t]{2}{*}{1} & Tomato & 1867.34 & -0.91 & 0.030 & -0.177 \\
\hline & & & $(0.61)$ & & \\
\hline \multirow[t]{2}{*}{2} & Brinjal & 1283.77 & -0.45 & 0.006 & -0.076 \\
\hline & & & $(0.71)$ & & \\
\hline \multirow[t]{2}{*}{3} & Ladyfinger & 3335.21 & $-8.01 *$ & 0.100 & $-0.313^{*}$ \\
\hline & & & $(2.9)$ & & \\
\hline \multirow[t]{2}{*}{4} & Cucumber & 1747.28 & $-3.06^{*}$ & 0.250 & $-0.500^{*}$ \\
\hline & & & $(0.63)$ & & \\
\hline \multirow[t]{2}{*}{5} & Cauliflower & 1827.73 & $-1.41^{*}$ & 0.090 & $-0.308^{*}$ \\
\hline & & & $(0.52)$ & & \\
\hline \multirow[t]{2}{*}{6} & Cabbage & 859.42 & 0.49 & 0.007 & -0.089 \\
\hline & & & $(0.71)$ & & \\
\hline \multirow[t]{2}{*}{7} & Pea & 1878.09 & $-2.85^{*}$ & 0.220 & $-0.467^{*}$ \\
\hline & & & $(0.64)$ & & \\
\hline \multirow[t]{2}{*}{8} & Radish & 786.23 & -0.53 & 0.030 & -0.161 \\
\hline & & & $(0.39)$ & & \\
\hline \multirow[t]{2}{*}{9} & Potato & 986.52 & -0.23 & 0.003 & -0.052 \\
\hline & & & $(0.53)$ & & \\
\hline
\end{tabular}

Note: Figures in the parentheses indicate standard errors of regression coefficients

*significant at $1 \%$ level of probability, ** Significant at $5 \%$ level probability

Table.5 Correlation coefficients between prevailing wholesale prices of vegetables in different markets

\begin{tabular}{|l|c|c|c|c|c|c|c|c|c|}
\hline Markets & \multicolumn{7}{|c|}{ Correlation coefficient for different vegetables } \\
\cline { 2 - 11 } & Tomato & Brinjal & $\begin{array}{l}\text { Lady } \\
\text { finger }\end{array}$ & Cucumber & Cauliflower & Cabbag & Pea & Radish & Potato \\
\hline $\begin{array}{l}\text { Baijnath- } \\
\text { Kangra }\end{array}$ & $0.939^{*}$ & $0.788^{*}$ & $0.962^{*}$ & $0.861^{*}$ & $0.913^{*}$ & $0.817^{*}$ & $0.915^{*}$ & $0.899^{*}$ & $0.803^{*}$ \\
\hline $\begin{array}{l}\text { Baijnath- } \\
\text { Bhunter }\end{array}$ & 0.384 & 0.415 & - & $0.701^{*}$ & $0.674^{*}$ & 0.457 & $0.777^{*}$ & $0.636^{* *}$ & $0.814^{*}$ \\
\hline $\begin{array}{l}\text { Baijnath- } \\
\text { Jalandhar }\end{array}$ & $0.904^{*}$ & 0.327 & - & $0.890^{*}$ & $0.809^{*}$ & 0.471 & $0.764^{*}$ & $0.749^{*}$ & $0.588^{* *}$ \\
\hline $\begin{array}{l}\text { Baijnath- } \\
\text { Pathankot }\end{array}$ & $0.918^{*}$ & 0.066 & - & $0.883^{*}$ & $0.657^{* *}$ & $0.847^{*}$ & - & $0.638^{* *}$ & $0.771^{*}$ \\
\hline $\begin{array}{l}\text { Baijnath- } \\
\text { Hoshiarpur }\end{array}$ & 0.095 & 0.290 & - & $0.845^{*}$ & $0.709^{*}$ & $0.877^{*}$ & $0.816^{*}$ & $0.647^{* *}$ & $0.692^{*}$ \\
\hline
\end{tabular}

Note: * denotes $1 \%$ level of significance

$* *$ denotes $5 \%$ level of significance 
Fig.1\&2 Seasonal indices of arrivals and prices of tomato in the market and seasonal indices of arrivals and prices of Brinjal in the market
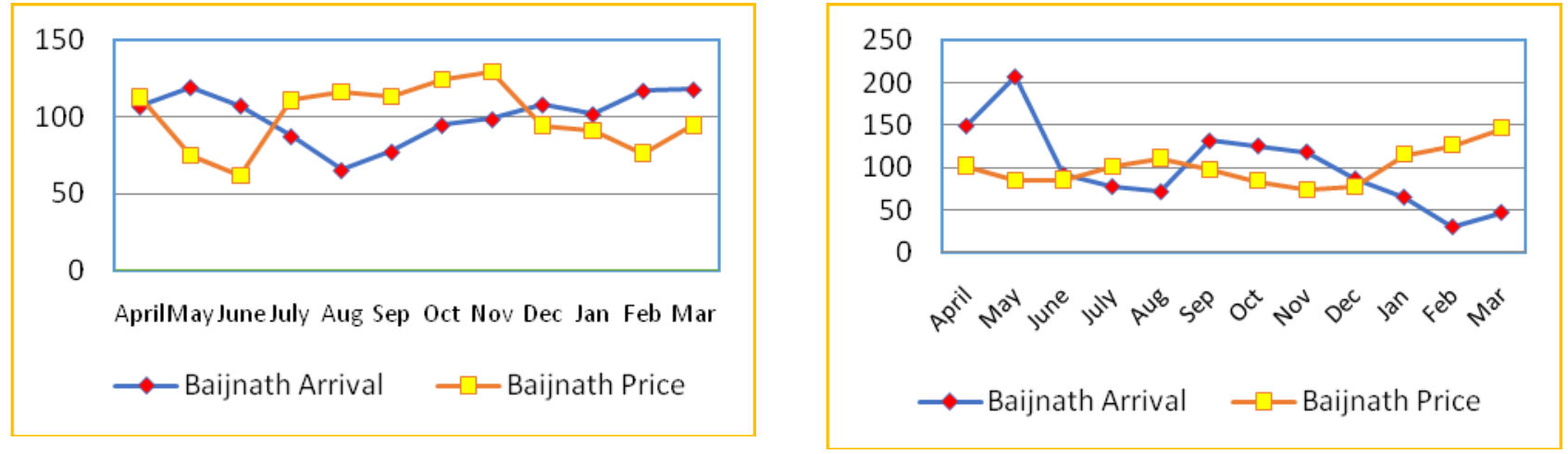

Fig.3\&4 Seasonal indices of arrivals and prices of ladyfinger in the market and Seasonal indices of arrivals and prices of cucumber in the market
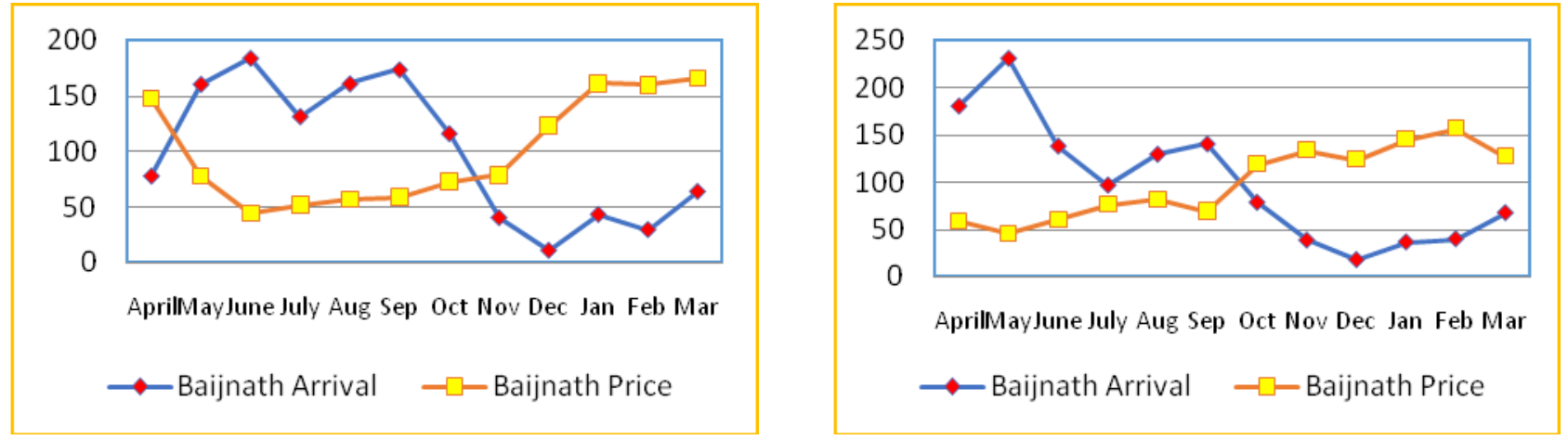

Fig.5\&6 Seasonal indices of arrivals and prices of cauliflower in the market and Seasonal indices of arrivals and prices of cabbage in the market
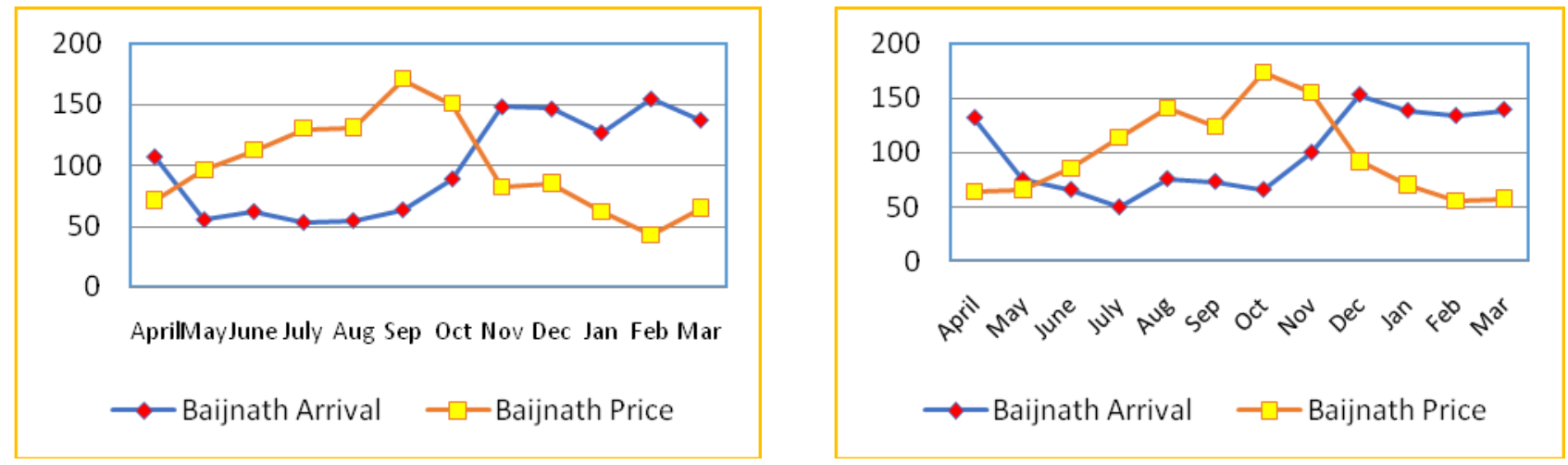
Fig.7\&8 Seasonal indices of arrivals and prices of pea in the market and seasonal indices of arrivals and prices of radish in the market
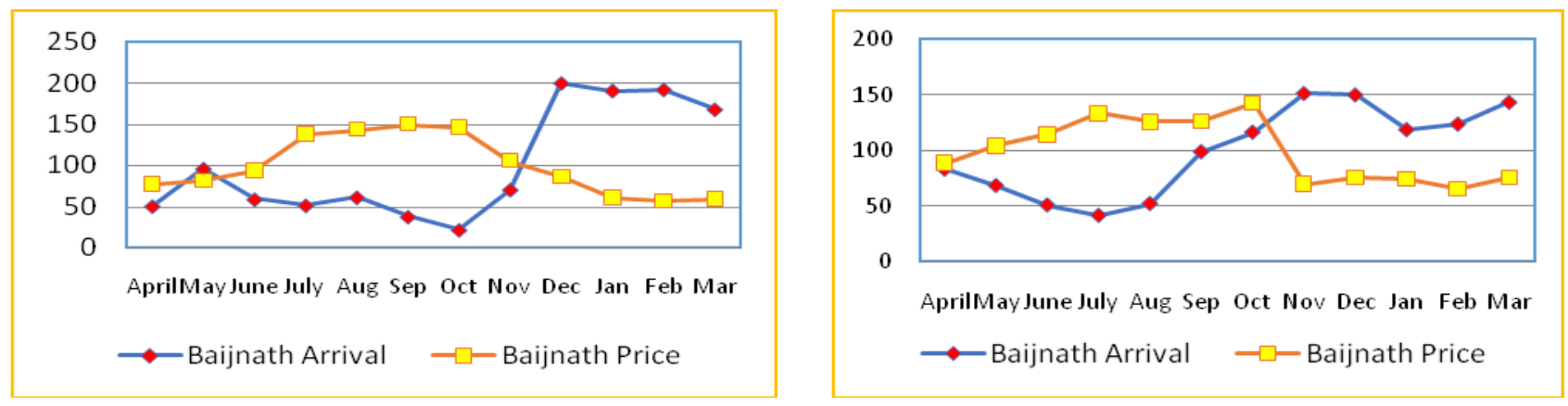

Fig.9 Seasonal indices of arrivals and prices of potato in the market

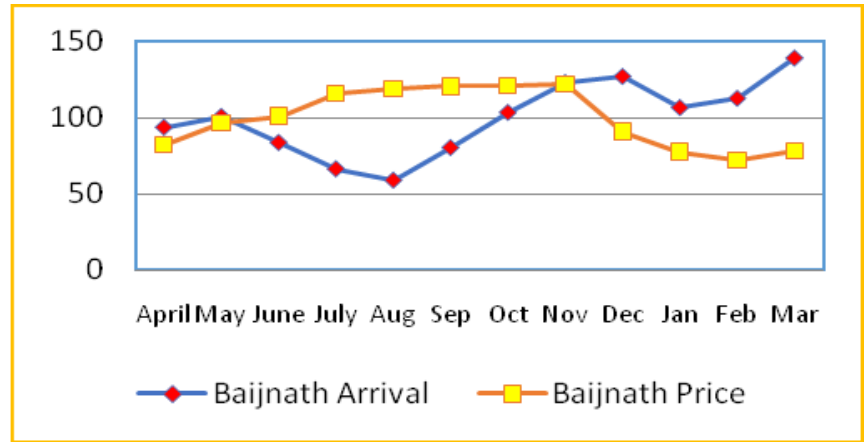

\section{Market integration}

Integrated markets are those markets where prices are determined interdependently means that the price changes in one market would be fully transmitted to other markets. For tomato (Table 6) the correlation coefficient calculated from market prices showed that Kangra, Jalandhar and Pathankot markets were found to be highly correlated with Baijnath market as the correlation coefficient was turned out to be more than 0.90. In case of brinjal, the correlation coefficients between Baijnath and Kangra market was recorded to be 0.79 which showed that both the markets were highly integrated but there was no integration of Baijnath market with the markets located outside the state. The Baijnath market was highly correlated (0.96) with Kangra market for ladyfinger. For cucumber, the Baijnath market was moderate to highly integrated
(0.701 to 0.890$)$ with other markets of the state and outside the state. The correlation coefficients calculated from the market prices for cauliflower, radish and potato showed that all the selected markets were moderate to highly integrated with each other. The Baijnath market for pea was moderately integrated with the markets located outside the state but was highly integrated with the markets located within the state.

Due to the perishable nature of vegetable supply of these commodities are inelastic. The trends in arrivals during the period 2010-11 to 2015-16 showed a significant increase in case of lady finger, cauliflower, pea, radish and potato. On contrary, the average monthly prices of all the vegetables showed a significant increase. Among all the vegetables, the prices of lady finger showed a maximum rise of Rs. 24 per quintal per 
month. The study has confirmed the negative relationship between market arrivals and prices.

The regression coefficient was found negative for all the vegetables but was found statistically significant only for lady finger, cucumber, cauliflower and pea. The arrivals and prices of vegetables in the market showed the high degree of seasonal variation.

In the case of tomato, brinjal and lady finger the arrivals were at peak level during May, while for cucumber these were maximum in the month of June, while the prices were low during these months. For cauliflower and cabbage, the arrivals were maximum in the month of February and December, respectively.

The farmers generally grow the vegetable crop without any consideration of the trends in the market prices. They should be persuaded by the extension agency to modify their conventional production programmes and supply of these vegetables to minimise the losses and take advantage of better prices situations for respective vegetables.

\section{References}

Fielder LL Jr and Osagie EI. 1985. Analysis, forecasts and seasonal pattern of monthly prices and quantities, Louisiana farm products. DAE, Research Report No. 642. pp 73

Jadhav MC, Ulemale DH and Borkar AN. 2011. Trends and seasonal variation in arrivals and prices in Amravati district. International Research Journal of Agricultural Economics and Statistics. 2(2): 232-235.

Kumar V, Sharma HR and Singh K. 2005. Behaviour of market arrivals and prices of selected vegetable crops: A study of four metropolitan markets. Agricultural Economics Research Review 18: 271290

Naidu MG, Kumari VM and Srikala V. 2014. Behaviour of market arrivals and prices of red chillies (Capsicum annum). Plant Archives. 14 (1): 511-519.

Reddy BS, Chandrashekhar SM, Dikshit AK and Manohar NS. 2012. Price trends and integration of wholesale markets for onion in metro cities of India. Journal of Economics and Sustainable Development 3: 120-12.

Sharma H and Burark SS. 2015. A study of seasonal price behaviour and concentration of maize in Rajasthan. International Research Journal of Agricultural Economics and Statistics 6 (2): 282-286.

\section{How to cite this article:}

Jyoti Chaudhary, Harbans Lal and Singh, H.P. 2019. Behaviour of Market Arrivals and Prices of the Selected Vegetables: A Study of Baijnath Regulated Market of District Kangra, Himachal Pradesh, India. Int.J.Curr.Microbiol.App.Sci. 8(01): 1454-1462. doi: https://doi.org/10.20546/ijcmas.2019.801.155 